Historic, Archive Document

Do not assume content reflects current scientific knowledge, policies, or practices. 


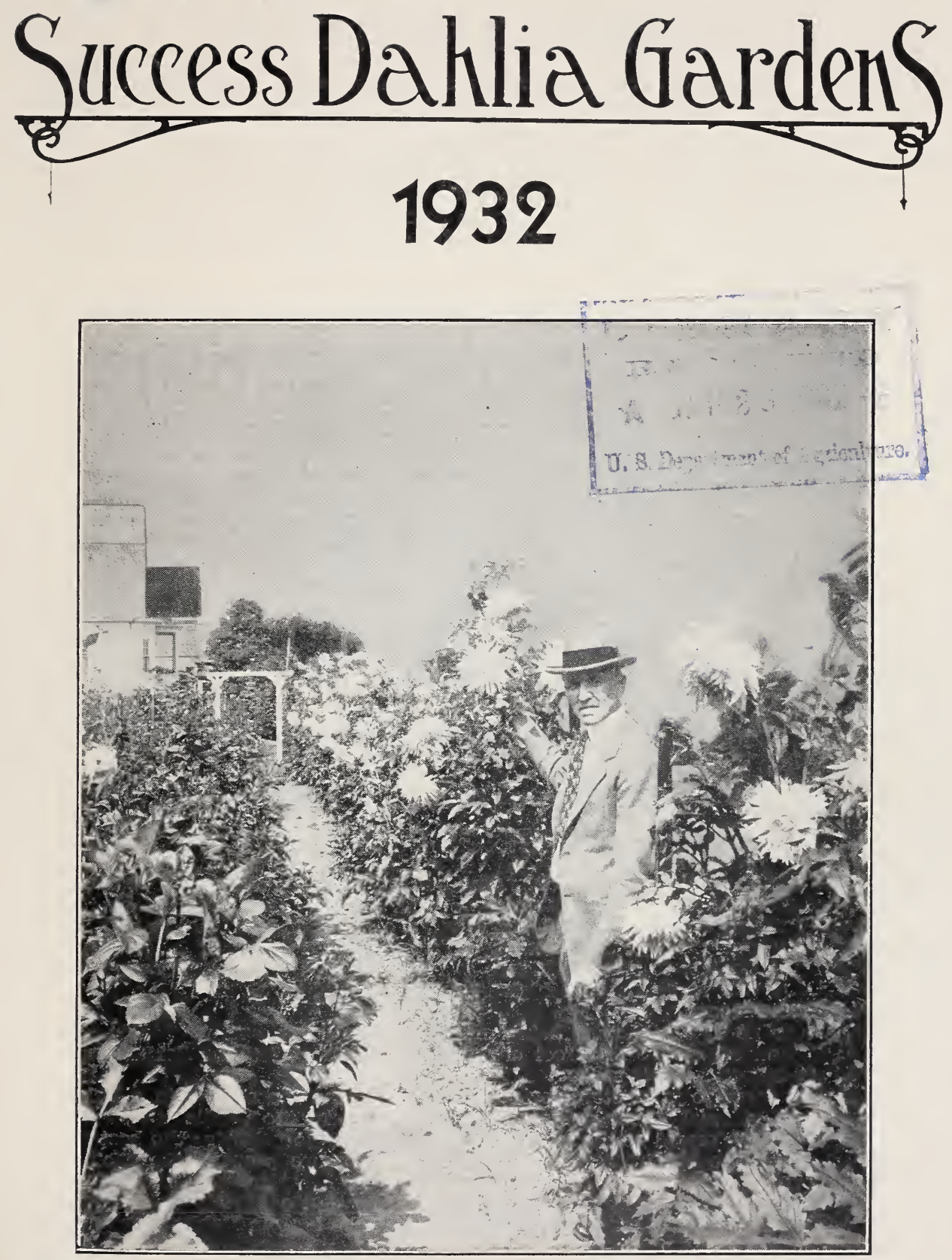

SECTION OF OUR TRIAL GARDEN

\section{$s$}




\section{GENERAL INFORMATION}

TERMS: Remittance with order on or before shipment. Retail orders are delivered prepaid. Please remit by bank draft, Post Office Order, or registered mail. No stock sent C. O. D. unless 50 per cent of purchase price accompanies order. Remit by Postal Money Order from Canada or other foreign countries.

URDER EARLY and avoid disappointment should the variety desired be sold out. Orders are filled in rotation as received. If for any reason we are unable to fill an order complete we will assume no responsibility in excess of purchase price of stock we are unable to fill order on.

SHIPPING: We begin shipping tubers about April 15th unless otherwise desired. Green plants are shipped from May 15th to June 15th.

SUBSTITUTION: We never substitute without permission, but suggest you mention a second choice.

CULTURE: Complete instructions for growing Dahlias will be sent with each order.

GUARANTEE: All stock is guaranteed to be true to name and in growing condition upon arrival. If for any reason it is found otherwise please return at once and we will cheerfully replace or refund purchase price if requested to do so.

GREEN PLANTS: Our green plants are all base cuttings, which make stocky, well rooted plants that will grow and produce fine blooms and make good clean tubers. Our plants are grown in a specially built greenhouse for this purpose. They are grown under moderate heat, and at the proper time are hardened off in cold frames. We have shipped green plants to California and they arrived in fine condition.

COMMERCIAL GROWERS: We cater to a high class retail trade, but we will allow the usual trade discount on our own introductions and on other varieties where our stock will permit, except where prices are net. Write for discount mentioning varieties wanted. We grow many varieties not listed.

SPECIAL BARGAINS: Collections of 6 named varieties $\$ 5.00$ and $\$ 10.00$. Our selection, all different, large blooming kind.

AbBreviations: C., Cactus; H. C., Hybrid Cactus; D., Decorative; P., Peonyflowered; I. Dec., Informal Decorative; F. Dec., Formal Decorative; S. C., Semi-Cactus.

NOTICE: This list cancels all previous prices.

\section{OUR GREETINGS FOR 1932}

$A \mathrm{~T}$ this season of the year, in extending our warmest greetings and best wishes

to our many customers and friends, we wish also to thank them for their generous patronage and the confidence they have shown in our Dahlias and in our reputation for giving full value for every dollar.

We deeply appreciate this confidence and are satisfied that the following list of new creations will maintain that high standard of quality which in the past has earned that confidence.

There are no better Dhalias being offered at any price, and we highly recommend each and every one and feel confident that many of these Dahlias will be Show Room sensations this season.

A happy surprise is in store for you, if you like the sensational in a Dahlia,the kind that will make your garden a meeting place for the Dahlia fans, the kind that will draw the crowd at the shows and bring home the prize for the best flower in the show or the largest in the show, the kind we are proud to have our customers grow.

Your success in growing prize winners with our bulbs is of more importance to us than winning prizes ourselves. We introduce the best in Dahlias for our customers to win with.

To the newcomer and prospective customer:

We respectfully solicit your patronage and assure you that your orders will receive our personal attention. A trial order will convince you that our stock. service and business methods are all designed to make you one of our "SUCCESS FAMILY".

No transaction is complete with us until our customer is satisfied in every way. Sincerely yours,

CHARLES G. REED 


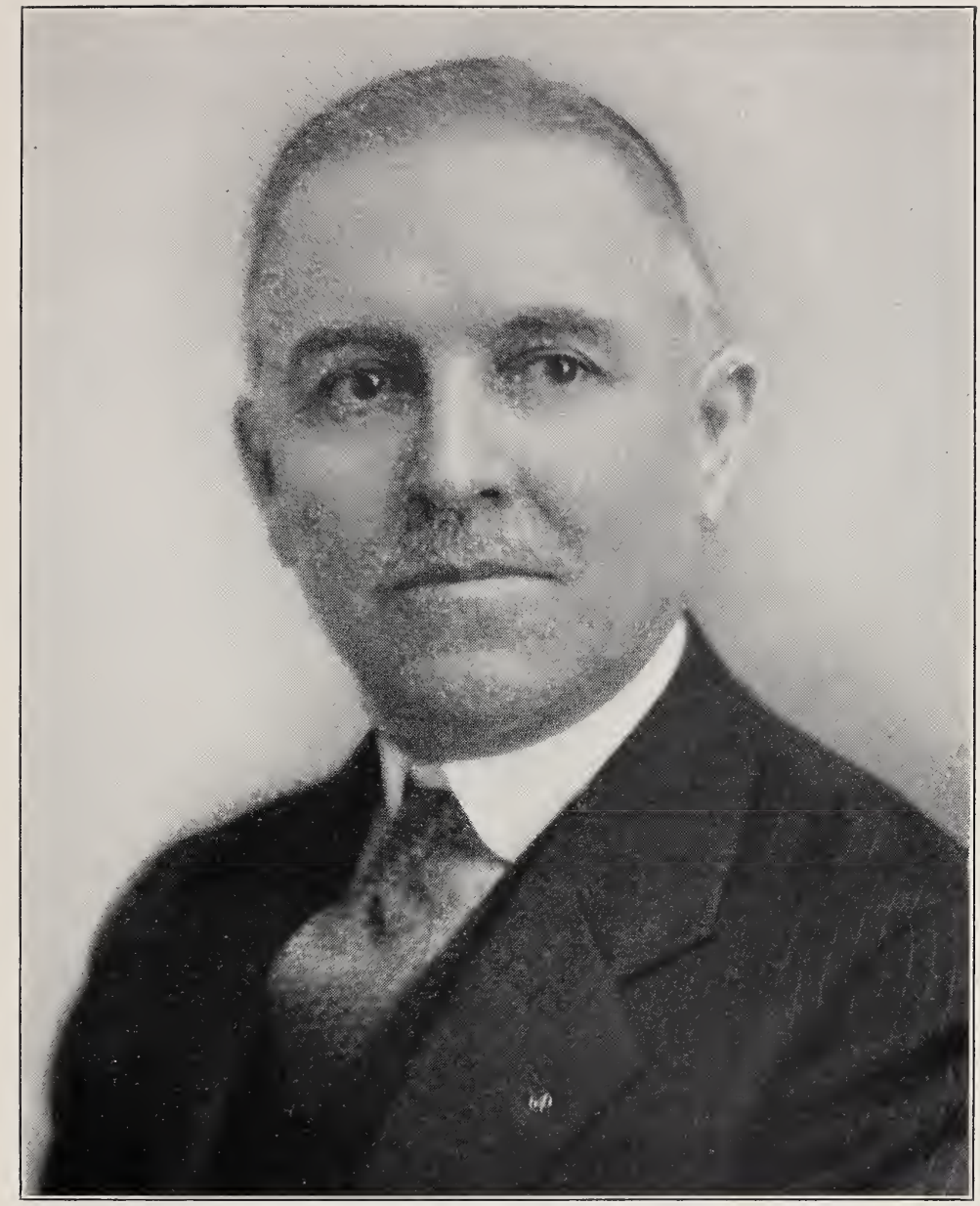

CHARLES G. REED

Proprietor of Success Dahlia Gardens

It is with pleasure we announce our dependable 1931-1932 introductions and other outstanding Dahlias that we highly recommend. We have used the originator's description in describing the Dahlias in this Catalog. 


\section{To Our Customers and Friends:}

When receiving a catalog from a friend I always feel more interested in it than I do in a catalog I have received from a stranger. Possibly the readers of this catalog may have the same feeling. As it is not possible for me to meet you all personally I will tell you somewhat about the friend who has sent you this catalog.

For nearly thirty years I have been and still am actively engaged as an official of one of our large and progressive local concerns, and Dahlias have been my hobby. While riding my hobby, my interest in Dalllias developed and I added to my gardens, branching out into the Commercial field as a means of sharing with others the new creations and the better varieties of this wonderful flower.

A few years ago I purchased the business of Mr. J. J. Broomall of Eagle Rock, California, who is known to be the outstanding producer of the best in Dahlias. $\mathrm{Mr}$. Broomall now devotes his entire time to the development of new creations, which will be introduced exclusively by the Success Dahlia Gardens, of which I am the proud owner.

Naturally I have always been very much interested in the success of the American Dahlia Society, serving several year's as a vice-president, also on numerous committees. I have been Chairman of the Trial Garden Committee since it was appointed, and was instrumental in having the "White Showers" irrigation installed at the gardens by the American Dahlia Society and the Connecticut Agricultural College at Storrs, Conn.

Some of my other Dahlia activities are,-

Charter member and past President of the Dahlia Society of New England.

Organizer and past President of the National Association of Commercial Growers, Inc.

Honorary Vice-President of the Dahlia Society of California.

I am Eastern representative of Mr. C. W. Balley of Palo Alto, California, an outstanding origination of Dahlias.

Show manager of the Lawrence Flower Show, sponsored by the Lions Club of which I am a member. This show was given recognition by national magazines as one of the outstanding flower shows held in the east last season.

It has also been my pleasure and good fortune to act as judge at many of the Eastern shows, including the National Show held in New York

Dahlias are my inspiration, not only through the satisfaction and joy of watching them grow and come into bloom, but for the many close and lasting friendships they have brought to me, for there is no business, sport or hobby that will bring you in contact with as many real fine people as are to be found among flower growers.

No doubt you have some Dahlia friend you fan with. I would enjoy being in on that chat. About the new Dahlias that found themselves on the American Home Honor Roll, about our disappointments and our successes in growing and exhibiting, about the Trial Gardens, about our pet theories and so many other subjects dear to the heart of a Dahlia fan.

From one Dahlia lover to another, I hope this informal introduction will be accepted in the spirit in which it is offered, and that you will accept me into your friendly discussions. A line regarding your difficulties will bring a prompt and friendly response from me, and I shall enjoy reading about your successes.

If the past season brought disappointment, let us live in hope of a better season ahead, and when we wander through our garden in all its glory and wonder, the disappointments will be forgotten.

More and better Dahlias in every garden, is my sincere wish for you all. 
To Our Patrons and Friends:

We are pleased to announce that we have been fortunate in securing Mr. Charles G. Reed of the Success Gardens, Lawrence, Massachusetts, to represent us in the Eastern market. Mr. Reed is one of the best known Dahlia growers on the Atlantic Seaboard. He has been growing our Dahlias and is therefore in position to speak of their merits when grown under Eastern conditions. All orders originating in the territory east of the Mississippi River should be sent direct to Mr. Chas. G. Reed, 171 Ferry St., Lawrence, Mass. Orders from the Pacific Coast and all territory west of the Mississippi should be sent to us as heretofore.

In being relieved of the responsibility of handling the Eastern trade we will have more time to devote to the creation of superior new varieties which we hope to offer you in the near future. In this connection, might add that we have some very fine ones to release this season.

Yours for more and better dahlias,

$$
\text { C. W. BALLAY }
$$

\section{A Message to My Friends:}

Quite a number of my friends and former customers not understanding why they fail to receive my catalogue, I feel that an explanation will be in order. Owing to failing eyesight and inability to properly attend to my rapidly growing Dahlia business, I disposed of my mail order business to Mr. Charles G. Reed of the Success Dahlia Gardens, Lawrence, Mass.

All requests for catalogues and information in regard to prices, etc., should be addressed to the Success Dahlia Gardens, Lawrence, Mass., as I have retired from the mail order business and will issue no more catalogues.

I want to thank my friends for the many favors I have received in the past, and to assure them that they will receive the same careful attention from Mr. Reed as I have endeavored to give in previous years.

I expect to continue my work at the Eagle Rock Dahlia Farm in my efforts to improve the Dahlia, and Mr. Reed will have the sole right of introducing the new varieties that I hope to be able to develop.

$$
\text { Sincerely and gratefully yours, }
$$




\section{NEW INTRODUCTIONS, 1931-32}

\section{AMERICAN LEGION (A. D. F.)}

$A$ beautiful yellow semi-cactus; the wonder Dahlia of the day. The tall, robust bush, with its heavy green foliage, holding the giant, deep flower boldly in the air on splendid long stems, makes a rare and extremely showy effect. Flowers $131 / 2$ inches in diameter and 9 inches in depth were shown at the Atlantic City Flower and Garden Pageant, winning the Gold Medal for the best undisseminated seedling of New Jersey origin; Gold Medal for the most worthy undisseminated seedling (open to all), $\$ 150.00$ in cash and the Am. erican Home Achievement Medal for the dahlia or dahlia exhibit which contributed most to the progress of the dahlia in a class of 710 entries. $\Lambda_{t}$ Camden it won the Gold Medal for the largest and most perfect dahlia. It has never been defeated.

Roots, April 1st delivery, $\$ 15.00$ net. Plants, May 15th delivery, $\$ 7.50$ net. ACHIEVEMENT (Inf. Dec.) (Ballay)

Gold with bronze shadings. This year we beg to submit a good Dahlia that carries with it the most coveted honor. Winner of the $1930 \mathrm{Am}$ erican Home Achievement medal at the Palace Hotel for the best new introduction west of the Rocky Mountains, we have given it the name that will emphasize its position. It has been tried out in both East and West with equal success. In depth as well as diameter this Dahlia is one of the very largest grown, and the formation of the flower is most pleasing, the many petals being curled and twisted in an artistic fashion. The good substance insures a wealth of perfect blooms under all weather conditions. Stems could not be improved upon either as to length or strength. This variety was one of the outstanding new Dahlias at the National Show in New York in 1931 and on the Pacific Coast. Another Honor Roll Dahlia.

Root $\$ 10.00$. Plant $\$ 5.00$

\section{BETTY COLTER (I. Dec.) (Success)}

This is a most charming new introduction that has caused favorable comment from many of the most prominent judges in the East. Derrill W. Hart describes this variety on the American Home Howor Roll for 1931 as follows, "One of our favorites among the new Dahlias. The color is distinctive and pleasing, an even shade of light salmon red throughout, shading to old rose at base of long rolled petals. The flower is nicely formed on good stems." We have never seen better stems on any Dahlia and this variety should appeal to those who like something different in their garden.

Root $\$ 10.00$. Plants $\$ 5.00$

\section{CARMANIA (I. Dec.)}

This imported Dahlia was one of the attractions in our garden the past two years and is now re leased for the first time. This is not a monster in size but makes up for that in its real beauty. It is a profuse bloomer of 8.9 inch bloom held perfectly erect, facing, on stiff stems. A brilliant yet deep yellow, with rich glowing center shading to orange at base of netals. There is a sparkling attractiveness in this variety that is seldom seen in a Dahlia. As a cut flower or for basket disolay there arc few Dahlias that can compare with this one.

Root $\$ 5.00$. Plant $\$ 2.50$

\section{DAILY MAIL (Dec.)}

The sensational giant of 1930 in England. WVe imported this varietv and consider it one of the hest of our importations in the matter of size and habits. The color is unusual in a Dahlia as the blending of deep ycllow and orange shades give the bloom a soft, warm color that appeals to those who like delicate shades in a Dahlia. A remarkable characteristic of this variety is the continual flow of huge flowers which the plants produce with ease, from first to last. Stems are wiry and strong.

Plants only $\$ 3.00$ net

\section{EAGLE ROCK FANTASY (1. Dec.) (Broomall-Success)}

We wish every Dahlia grower could see this wonderful Dahlia when in full bloom. It is a glorious Informal Decorative of monster size, imposing and beautiful in form and color. Huge broad florets tapering and tastefully notched at tips. We can honestly say that this Dahlia attracted more attention than any other Dahlia in our garden except our new monster white "Margaret E. Broomall". Here is how Derrill W. Hart describes it on the American Home Honor Roll for 1930. "This Dahlia will achieve universal acceptance. It is another wonder origination of a Dahlia wizard, who must be working along very definite lines in breeding. Clear, mallow pink, of great size and depth. It is more like Mrs. Frances E. Bullard than any variety that we can name, but an improvement on that wonderful variety in both form and color. All pink and with larger flowers. Received a Certificate of Merit at Storrs, and we saw it growing there and in its home garden. Among the finest of the 1930 Dahlias." The habits of this variety are ideal, the best of stems that are long, straight and stiff with the monster bloom set just right to look one straight in the face, the foliage is medium dark green and seems to be imnune from insect attack. It is different, it has size and then some. and is bound to be a consistent winner in the show room.

In 1931 this was one of the best Dahlias in the show room. It won for the largest Dahlia at the Palace Hotel Show and the second best Dahlia in the whole show. It was shown 14 inches and over in many shows. This variety won for the best in the show at Columbia by one of our cus tomers who writes, "I had four "Eagle Rock Fan tasy'. blooms, took first in the three vase class, first in the single class and one bloom in the vase wor for the best in the show." The same grower won the $\$ 75.00$ vase at the State Fair Show with Fan tasy. Not so bad for an amateur. It has won other prizes galore the first year out. If you want a winner and one that will grow anywhere with out "petting" try this one.

Root $\$ 15.00$. Plant $\$ 7.50$

\section{EAGLE ROCK PEACH (Dec.) (Broom. all-Success)}

IIr. Broomall describes this new variety as a large, deep rose-pink that should nlease those that like size and beauty combined. The stems are all that could be desired. This variety should be planted early as it is a late bloomer. We have but a very few roots to offer on this variety thi season so would advise ordering early.

Root $\$ 15.00$. Plant $\$ 7.50$

\section{EAGLE ROCK SUPERBA (Dec.) \\ (Broomall-Success)}

Another one of Mr. Broomall's new originations that he considers one of his very best. There 1 color on the chart that is exactly like the color in this variety, but the nearest being a light amaranth pink, a much more attractive color than our last year's introduction Eagle Rock Fantasy The originator considers it a better Dahlia than Fantasy. It is about the same size and habits except in color. $\mathrm{WC}^{\circ}$ have never grown a Dahlia 
of the same color. The stems are perfect and hold the large bloom erect. We predict a bright future for this Dahlia. Our stock is very limited.

Root $\$ 20.00$. Plant $\$ 10.00$

\section{FURY (For. Dec.) (Ballay)}

Rose and copper with a reverse of deep rose. This is a huge dahlia of rather odd but pleasing color. First flowers will measure 11 or 12 inches in diameter and the size is well maintained through the whole season. The plant, of medium height, is a good producer and every flower counts as the centers are always closed and the stems satisfactory. Fine for garden decoration and serviceable for use in a collection of large dahlias.

\section{Root $\$ 10.00$. Plant $\$ 5.00$}

FULL MOON (For. Dec.) (Ballay) -

Canary yellow. Here is a variety that can truthf ully be called a superlative Dahlia. The big bold flowers easily measuring 12 inches across are regularly formed of very broad flat petals that terminate in a perfectly full and artistic center. The thickness and strength of the stem are par ticularly noticeable and the flower is always unright, never facing the least bit to the side. We have never seen a variety more consistent, everv flower being large and perfectly formed, and the foliage is alwavs clean and bright. At the Boston Show this Dahlia won the Gold Medal as the best Dahlia of California origin and won first prize in largest bloom class.

Root $\$ 15.00$. Plant $\$ 7.50$

\section{GOLDEN HARVEST (Hyb. Cac.)}

A most striking variety, producing enormous blooms of a beautiful sulphur-yellow in color, with no shading. The blooms are held perfectly erect on the best of stems and by disbudding it is nos sible to grow blooms larger than Siskiyou. The plants are a mass of bloom from early to late in the season. I have never seen such large buds before the petals commence to unfold and reminds one of the enormous exhibition Chrysanthemums as they open up, only much larger. A winner. Height, 3 feet. This variety was another of our introductions that made good wherever exhibited. A customer won first prize with this Variety in the keonest competition at the National Show at Atlantic City in 1931.

Root $\$ 7.50$. Plant $\$ 3.50$

\section{INDIANA MOON (I. Dec.) (Martin)}

This variety was awarded a certificate at the Trial Gardens at Storrs in 1930 and found itself a place on the American Home Honor Roll in 1931. This variety has won many first prizes in the Middle West where it was originated. It is a good Dahlia in everv way and grows without an. forcing up around 10 inches and the bloom are held erect on long, stiff stems. The color of this variety is difficult to desrribe as there are so many colors in its make-un. The Trial Garden describ-s it as flesh ocher with faint lines of sninel nink running through some of the petals. With us it showed plents of blending of colors to mak ${ }^{-}$it most attractive.

Root $\$ 10.00$. Plant $\$ 5.00$

\section{LORD LAMBOURNE (Dec.)}

Another imnorted variety that the originator describes as follows: One of our greatest successes as raisers to date, and we can hardly exaggeratc in describing it. The blooms are tremendous size, and it has a most pleasing form, whilst the stems are so strong that the blooms are easily held erect. The color has been described as sunset harmony of pink and gold, but the old gold and bronzy tints predominate.

Root $\$ 5.00$. Plant $\$ 2.50$ MURPHY'S MASTERPIECE (Inf. Dec.) (Murphy-Success)

Named in honor of the late Thomas Murphy of Peabody, Mass., who made so many rich contribu- tions to the Dahlia world. It is beyond the ability of the writer to adequately describe this mag nificent Dahlia. There has been a demand for a real red Dahlia and we believe that in this variety that the desire has been fulfilled in every way. We have admired this Dahlia for years as we saw it growing in the garden of its originator. It truly was far ahead of any other Dahlia that he had ever originated and it is the largest and best red Dahlia that we have ever seen. It has size and then some, it has a color all its own and it will not burn, or at least we have never seen a bloom that showed the least bit of burning or fading in our hottest weather. It does not shed its petals but they just dry up on the plant and the center holds perfect to the last. It has heavy, thick foliage that holds no attraction for the insects. The monster blooms are held erect on stiff stems. This is how Derrill W. Hart describos this variety in the American Home Honor Roll for 1931. "A huge, deep, dark red shading towards garnet, and a flower that grows large without much encouragement. When first shown in Boston be fore the originator's death, this big Dahlia won the cup offered by the President of the Massachusetts Horticultural Society as a most worthy noveltyand novelties other than Dahlias were also in con petition. Awarded also the American Home Achievement medal by the Dahlia Societs of New England in 1931 at Boston." Mr. Murphy also won for the largest bloom in Boston showing a 12 inch flower. We know of no other Dahlia that will cause more of a sensation in the show room than this variety this season. Remember this is a real red and it was awarded a certificate at Storrs in 1931.

Root April 1st delivery $\$ 15.00$. Plant $\$ 7.50$

\section{MISS ANNIE LILE (Dec.)}

Another imported introduction that deserves a place in any collection where the unusual is desired. We have seen no Dahilia that has the artistic formation of this variety. The blooms are not over 8 inches in size, but when arranged in a basket for a display, it has been one of our most outstanding varieties. Many admirers refer to it as being like a Chrysanthemum in formation. The florets reflexing. curling and interlacing making flowers very full and deep. Color pink with rose shadings at base and center. Flowers held erect on stiff stems.

Root $\$ 5.00$. Plant $\$ 2.50$

\section{MONTALVO (Inf. Dec.) (Ballay)}

Golden bronze shading to a deep bronze center. Size seems to characterize most of our introductions this year, but not at the expense of beauty. We have been asked repeatedly for extremelv largr ones and this time we are able to supply them with a vengeance. Montalvo is another 12 inch Dahlia when grown with ordinarily gond care and it has vroportionate depth and strength of stem. There is great beauty in the colnring as vou can imagine, and when you have charm in color, $\mathrm{com}$ hined with massive size, perfect formation and the best growing habits, the variety may be defined as an up-to-the-minute Dahlia.

Root $\$ 15.00$. Plant $\$ 7.50$

\section{NARCISSA (Semi-Cactus) (Ballay)}

Bright daffodil vellow. We wanted a name that would express the freshness and warmth of early spring for this Dahlia and could think of nothine more apnropriate than the daffodil and the other vellow flowers of the narcissus familv. In the full formation of the flower there is also furthm suggestion of the double daffodil. This Dahlia averages 8 or 9 inches in diameter and is anotho? one that grows straight up on a ling perfect stem. Jt is striking in the garden, charming when cut, and has no faults whatever.

Root $\$ 10.00$. Plant $\$ 5.00$ 


\section{PEKIN (For. Dec.) (Ballay)}

Deep cerise rose. The color of this Dahlia somewhat reminds one of that oriental shadc sometimes called Chinese pink. The many petals of the large flower are quite regularly placed but are somewhat quilled toward the center so that the general effect is not severely formal. Long. stron stems hold the flower up well, and the growth of the plant is vigorous and healthy.

Root $\$ 10.00$. Plant $\$ 5.00$

\section{MRS. CHAS. G. REED (Dec.) (Garrity)}

In this new white we have a Dahlia that has never been defeated the first year out. Winning first prize in every class entered on the Pacific Coast. It has also the distinction of having won Certificates at Storrs Trial Garden and the North West Trial Garden in 1931, scoring 85 at Storrs and 87 at the North West Trial Garden. This is not the largest white in the world but it must have been good to make such a fine record in different sections where it was grown on trial the past season. The stems are all that could be desired and habits are good in every way. The originator has placed the pricc at

Root $\$ 10.00$ net. Plant $\$ 5.00$

\section{RUDY VALLEE (Broomall-Success)}

Semi-Cactus. In this varicty we have one of the most beautiful Dahlias ever offered. When the flowers begin to open they show chrome yellow at center, with a graduation of grenadine red as the flower expands, finally becoming solid grenadine orange red when in full bloom. The flowers are pleasing to look upon, and instantly catch and hold the attention of all who see them.

Flowers, large to very large, full centered, anil are held well above the clean-cut foliage on long. straight stems. Plant 5 to 6 fret high, with numerous strong laterals. Growth vigorous, which insures it against serious injury from insect attacks. A magnificent Dahlia that you cannot af ford to $b$, without. Winner of certificate $a^{t}$ Storrs trial garden 1930, scoring 86 points.

Root $\$ 10.00$. Plant $\$ 5.00$

\section{REV. S. MARRIOTT (Dec.)}

Another imported variety that should please the growers who like the darker varieties. The colns is deep plum. Dwarf plants witl bloom held erect on stiff stems.

\section{SATAN (Semi-Cactus) (Ballay)}

Root $\$ 3.00$

Flaming red with a slight touch of gold at the center. The exquisite coloring is at once fascinating, but what formation and stems. The blooms regularly measure 10 to 12 inches in liameter and 6 inches in depth, and the lon. horn-like petals, so perfectly rolled and incurver? give rare form and character to a flower of unusual brilliancy. The rugged, almost leafless. stems give the impression of being nearly as thick at the top as at the base. Large, fine blooms. which last a long time when cut as well as on the bush, continue to the very end of the season.

Derrill IV. Hart describes this variety as ful lows in the American Home Honor Roll for 1931

"This flaming scarlet with orange-salmon at the base of each petal was not shown in the East, but we saw it growing at Lawrence, Mass. The blooms are beautifully formed and the bush is ? fine grower. Surely this variety will be a tem?. tation to any Dahlia fan and better still he will not give himself cause to regret in yielding in this color sensation, one of the most brilliant we have seen in a Dahlia. Only a few Dahlias would feel comfortable near this one."

Satan was the Dahlia sensation on the Pacific coast this year where it has already made for itself a place on the American Home Roll of Honor. Its performance in the East has beein equally as good as in the land of its nativity.

Root $\$ 25.00$. Plant $\$ 12.50$

\section{SILVER RAY (American Cactus) (Broomall-Success)}

This variety is of a color that to us is very unusual in a Dahlia. It is a very light yellow. almost white and many visitors have remarked what a nice white, hut it is yellow. I know of 11 n other Dahlia that has any better stems or grow. ing hahits. The stems are clean and very long and strong. holding the large flowers erect, lookins rou in the face. Try this one and you will not regret it.

Root $\$ 7.50$. Plant $\$ 3.50$

\section{TIFFANY (Inf. Dec.) (Ballay)}

Bright apricot with a golden sheen. Good sub. stance in a Dahlia nowadays is a necessary requisite. We have discarded many seedlings for no other reason than that they lackerl this quality. Flowers of good sulsstance, delightful coloring and interesting formation, are the distinguishin' features of this new varicty. The average size of this Dahlia is about 10 inches. Stems are lonr and wiry. $O . K$. in every respect.

Root $\$ 10.00$. Plant $\$ 5.00$

\section{YELLOW WONDER No. 3560 (1. Dec.)}

Mr. Broomall considers this variety his best vellow to date. He grew it larger than Aztec Glory and its liabits are much better. A strong rugged grower, branching habit with the very large bloom held erect on the hest of stems. It is ? deep. rich yellow and will become one of the out standing Dahlias in the show room is our helief. This yellow made a great many friends the past season and manv remarked that it was better $+1, \ldots \cdot$ some of the new yellows that were shown in 19.31

Root $\$ 10.00$. Plant $\$ 5.00$ 


\section{We Present the Following Standard Varieties That Are Leaders in the Garden and Show Room}

\section{AMBASSADOR (Semi-Cactus)}

This beautiful Dahlia has alwavs been a prize winner. The color is a soft yellow center wir! salmon, amber and pink shadings, gradua!ly deepening towards the tips and outer floral rays. Has won prizes for the largest in the show. Sold for $\$ 50.00$ per bulb when introduced.

\section{AMERICAN TRIUMPH}

Root $\$ 1.00$

Winner of the American Home Sweepstakes at New York, 1929, for the most outstanding New Seedling in the entire show. Undoubtedly the finest true Cactus Dahlia to date. Such an unusual coloring, the brightest shade of pure Oriental red without a trace of any other color. The large flowers are deep and with good substance, and are held erect above a strong, medium tall bush. It will not only make a most worthy acldition to the Cactus class, in which there are so few good exhibition varieties, but an exceptionally good garden and cut flower, as there is no better keeping Dahlia in existence.

\section{ARTHUR W. GRAY (I. Dec.)}

Root $\$ 5.00$

1 flower that is new and of distinct individual it*. Placed on the American Home Honor Roll The color is rich, salmon-apricot, flushed orange and rose. The stems are rigid and long, holdi. the dark flowers facing you. The foliage is very thick and dark green, and does not have to be sprayed at any time. Good for exhibition.

Root $\$ 5.00$

\section{ALICE WHITTIER (S. C.)}

Our own introduction that is considered the best yellow hybrid cactus ever introduced. Its record as an exhibition flower is known from coast to coast as it has won the highest award in many exhibitions throughout the entire country. Beautiful, vigorous Dahlia that pleases all. Awarded certificates at three different trial gardens with a high score of 90 points.

Root 50 cents

\section{AMARANTHUS-}

Amaranth-pink, very large flowers, good stems. Height, $2 \frac{1}{2} 2$ feet.

Root $\$ 1.00$

\section{BETTY BROWNE (Dec.)}

Seedling of the beautiful pink Glory of Mon mouth. Color is spinel-pink, and old rose blend. deep lemon-yellow at base of petals. Flowers full centered and of large size, averaging 10 inches and over in diameter, and 6 to 7 inches in depth The large, well-built blooms are borne on stiff stems well above the foliage. Plant is of medium height, wide-spreading, and vigorous constitution. A good Dahlia in every respect.

Root $\$ 2.00$

BING (Dec.)

Deep cherry red with a lighter reverse. A fine clean dark red, large and distinctive. Petals are of velvet-like texture, broad and slightlv waved. Does not fade. Stem is straight and strong. IV think it is the prettiest and most satisfactory variety in this coloring. Good for all purposes.

Root $\$ 3.50$

\section{CAROLA (Dec.)}

Amber-rose. A positive old rose with an amber tint tliroughout the flower. This is a very at tractive coloring that many visitors admired. The plant is of medium height and is well covered with good flowers, early and late. Shape is quite formal, stem upright, general habit excellent.

Root $\$ 3.50$

\section{CELESTE (Dec.)}

Lilac pink overlaid with carmine. A very handsome large flower that is attractive especially because of its peculiar shadings of color. The well-branched plant produces deep, well-built blooms over a long period. There are no fault. noticeable to take from the general usefulness of this valuable addition to Dahlias of this color range.

Root $\$ 7.50$

\section{CHARLES SMITH (I. Dec.)}

This creation was originated in New England and we consider it worthy, and a pleasure for us to recommend it to our Dahlia friends. It at tracted much attention in our Boston and Madison Square Garden displays. Its one fault is a short stem, but by disbudding this can be overcome. It is the color of this variety that appeals to Dahlia lovers, cream at base of petals. then blending into a rich pink at the tips. The average size of the bloom is about nine inches, but can be grown much larger $b_{j}$ forcing and disbudding.

Root $\$ 5.00$

\section{CHARLES G. REED (F. Dec.)}

Purple-red. This is the color in plainest words. Exactly petunia-red is what an authority on dress materials called it-a lively shade not far from crimson. Was awarded First Prize for the best Dahlia of red coloring in the Palace Hotel Show. This variety is unusually large and is held up right on a perfect stem. Big, broad petals, a deep full center, and the great profusion of bloom have caused several of our visitors this year to exclaim that it was the most beautiful Dahlia they had ever seen. Bush is of rather low growth with the branching habit, which makes it ideal for all purposes. This Dahlia without doubt was one of the outstanding new varieties in 1930. It won many high honors in the hands of our customers. It also received a Certificate of Merit at Storrs. A sure winner.

\section{Root $\$ 7.50$. Plant $\$ 3.50$}

\section{CONQUISTADOR (Semi-Cactus)}

Soft creamy yellow, shading to a glowing pink at the base of the petals. The pink coloring is very pronounced and gives to the flower the appearance of being illuminated from within. This is a Dahlia built on a massive plant. The plant is extraordinarily tall and the flowers can be cut with 4-foot stems. The bloom is in proportion. being regular, rather coarse-petaled, broad and deep. Moreover, the texture of the flower is of the same vigorous quality, not being easily soiled by wind, sun or moisture.

Root $\$ 3.50$

\section{DR. JOHN H. CARMAN (F. Dec.)}

A large, dcep, broad-petaled, Tyrian-rose flower, tipped petunia and silver, of largest size helc? erect on stiff, heavy stems. A large leaf variety which means insect resisting plant.

Root $\$ 3.00$

\section{DOROTHY STONE (I. Dec.)}

A most outstanding Dahlia in every wav. It is a huge decorative of a deep, pure pink. This is a distinct and splendid exhibition variety. Very full center. Petals are thick and evenly placed. profuse bloomer. deep green leathery foliage. nedium to tall habit, stem straight upright and strong.

Root $\$ 5.00$. Plant $\$ 2.50$ 


\section{DERRILL W. HART (Dec.)}

Considered by many growers to be one of $\mathrm{Mr}$. Broomall's greatest originations; anyway it was good enough to win many high honors in the keenest competition. Color, capucine-yellow, shading to grenadine-red, in cold weather almost a copper color. The large, well-formed blooms are held erect on long, stiff stems. Universally admired by all who saw it.

Root $\$ 3.00$

\section{DONNA CALIFORNIA (Dec.)}

Deep rose pink suffused with lavender. The color is not new, but it is doubtless the largest Dahlia by far of that coloring. In fact, it is the largest Dahlia that we have ever grown in our gardens, 12 -inch blooms having been produced without effort through a long period. The flower is not particularly heavy, considering its great size, as its even petal formation is loosely arranged rather than solid. The stems are very strong and very long. We again won the prize for the Best Established Three-year-old at the Palace Hotel, this time with six blooms of this giant Dahlia. A most wonderful Dahlia in the East.

\section{Root $\$ 7.50$. Plant $\$ 3.00$}

\section{DOLOROSA (Dec.)}

Deep bluish lavender. The blue is just a little more pronounced than has appeared heretofore. Perhaps it is a step toward a real blue, if that much heralded specimen ever comes. At any rate, this is a very pleasing variety with big full flowers held upright on long, hard stems. The petals are somewhat pointed, the center is tight and holds well. Plant appears to have more flowers than leaves.

Root $\$ 7.50$

\section{EAGLE ROCK WONDER (S. C.)}

For tremendous size, perfection of form and habit of profuse blooming qualities and vigorous growth, I have seen no equal of this Dahlia. It was the outstanding feature in the garden. The color is mars-orange shading to orange-buff with tints of coral-pink and coral-red according to Ridgeway's color chart; the general effect being between orange and apricot. This Dahlia sometimes forms a number of adventitious buds on the back of the flowers; so far, probably not more than twenty per cent have done this. These buds. reminding one of Brussels sprouts, do not affect the appearance of the front of the flower. They can easily be removed before the main flower is fully developed, and it seems to me are caused by the extraordinary vigor of the plant, seemingly to give, an outlet to its unusual energy. This variety has never yet shown an open center even under the most unfavorable conditions. A monster. Height 5 feet.

The above is our last year's description and we want our friends to know that this wonder found its way to the top of the list in winning major honors in the show room. Derrill W. Hart thinks well of this Dahlia and expresses himself in describing this creation on the American Home Honor Roll in 1930 as follows: "This monster flower won as Largest and Most Perfect Bloom at Trenton and also as the Best Dahlia Originated Outside of New Jersey. Again, at Red Bank it won as Largest and Most Perfect Bloom in the Open-to-All Section. The color is a tawny orange flushed with gold and salmon, shading to pure gold at center. It is a very symmetrical flower and will be a consistent winner in the Specimen Bloom and Largest Bloom Classes." We think with his description and its record to date that it will be grown in every first-class garden where they like beauty and the monsters. It has both Many of our customers report that they had many blooms over 13 inches in 1931 and one re ports having it 9 inches deep. This variety seems to improve each season.

Root $\$ 10.00$. Plant $\$ 5.00$

\section{EAGLE ROCK BEAUTY (I. Dec.)}

A more beautiful combination of pink and cream than displayed in this glorious creation would be difficult to imagine. It is in a class by itself, and unanimously admired by all who saw it. It is vigorous in growth, with good habit, and strong stems holding the immense blooms erect, which are full to the center, and produced in abundance until frost.

\section{EDWARD THOMAS BEDFORD (Dec.)}

Root $\$ 1.00$

Surely there is no deep purple that can compare with it in size, for this one is a giant and the blooms are held perfectly erect on long, cane-like stems, and what a bloomer! Always covered with mammoth flowers. Please do not confuse this Dahlia with the old E. T. Bedford, this is a new one-and it's a wonder.

\section{EVA L. QUADLING (F. Dec.)}

Root $\$ 3.00$

Immense full centered blooms of the finest qual. ity. Color carmine and spectrum blended, back same with pale mauve veining, center ox-blood red. Was the sensation at the Cumberland Hotel Show in Bridgeton, N. J. It was also in the First Prize Collection of 12 best decoratives at the Santa Monica, California, and the Los Angeles, Calif ornia, shows.

Root $\$ 2.00$

\section{FAIR ELAINE (I. C.)}

Delicate old rose. An extra good variety that closely resembles the American cactus type in formation. The "pink Ambassador" we called it before it was named, although the petals are considerably more incurved than those of the older variety. For true beauty it is hard to surpass and the quantity of good flowers produced is the greatest we have seen; not that it is one of those varieties that require a lot of disbudding, for it is quite the opposite, but the numerous branches, both upper and lower, all produce good flowers until the very end of the season.

Root $\$ 3.50$

\section{FORT WASHINGTON (F. D.)}

Here is a Dahlia that can and has won many prizes of the largest in the show. Very seldom less than 10 inches without forcing. The larger flowers are held perfectly erect on long cane-stiff stems. Winner of many prizes in all classes for decoratives. Has size, refinement, a free bloomer, and the color is a most charming deep maroon.

Root $\$ 3.00$

\section{FITZJAMES (Dec.)}

Clear amber. The tall bushes are productive of many large blooms of a color that seems to promote harmony in whatever location it is placed. We have noticed that a bouquet that otherwise seemed quite ordinary was considerably improved by the addition of a couple of blooms of FitzJames. The formation of the flower is just regular enough to be pleasing, and the stem is good until late in the season.

Root $\$ 2.50$

\section{FABIOLA (Dec.)}

Pure unshaded lavender. This is a large and good Dahlia in the most pleasing shade of lavender we have seen. In November the color was still unchanged and the full, broad-petaled flowers would still have been suitable for exhibition. The first blooms are rather short-stemmed and should be disbudded accordingly in order to bring the next crop well out of the bushes. A Dahlia that will appeal to those who judge 2 variety by its late blooms.

Root $\$ 3.50$

\section{FORT MONMOUTH (Hyb. Cac.)}

One of the giants of the Dahlia world. The color is a rich crimson maroon (some say it is 2 
rich claret), with a brightness unusual in the darker tones, and just a faint tinge of bluish violet at the tips of petals. The flowers have long narrow petals, are well formed, full centered, of true hybrid cactus type, and of enormous size, attaining to a diameter of full 13 inches, and are borne on long, stiff stems high above the foliage and look you right in the face. Winning many prizes for the best in show.

\section{GABRIEL (Hyb. Cac.)}

Root $\$ 4.00$

Carmine pink, or what might be termed "wate:melon". This variety is an early and free bloomer, and the blooms are really spectacular. Very large and deep, they lead the garden in in terest in the early season. As the season ad vances the stem is not always good, especially if the plant is allowed to become too bushy. All things considered, we can recommend it as a Dahlia that will bring the grower much pleasure and cause his friends to gasp and wonder.

\section{Root $\$ 7.50$. Plants $\$ 3.00$}

\section{GRACE CURLING (I. Dec.)}

We wish every Dahlia grower could see this wonderful Dahlia in bloom. It is a glorious decorative of very large size, imposing and beautiful in form and color. The latter is white at base, then changing to lilac pink and rose. Huge broad florets, bluntly tapering and tastefully notched at tips. It requires no disbudding or trimming to have equally as large blooms at the end of the season as when they first bloom. Perfect stems, and they are long, bearing the big blooms well above the foliage. We know of no Dahlia that is more charming than this imported beauty.

Root $\$ 2.50$

\section{GAIETY (F. Dec.)}

Pale true pink. A Dahlia somewhat on the style of Jersey's Beauty but of a different color. It is not much larger than the older Dahlia but has the same good stems and similar formation. This variety is free blooming and is very useful and beautiful for interior purposes.

Root $\$ 1.50$

\section{GOODNIGHT (I. Dec.)}

We have grown many fine dark colored Dahlias, but we find in this variety a monster in size and the rich color of ox-blood red shaded maroon, is the greatest attraction in the garden and in the show-room. One of the outstanding Dahlias at the National Flower Show at Atlantic City, win. ning first prize for first basket. A sure winner.

Root $\$ 5.00$

\section{JANE COWL}

This magnificent decorative was without doubt the outstanding Dahlia that has been produced in the East since Jersey Beauty. It would be in1possible to list its winnings, as we are continually hearing of where it won for the best in the show. Mr. Derrill W. Hart in his Roll of Honor report in the American Home is as follows:

"Jane Cowl was the outstanding Dahlia in every show room. It would be impossible to enumerate the prizes won by this grand flower. Next to Jersey's Beauty we believe that Jane Cowl has the best record of any other variety introduced. It ranks with the immortals of the Dahlia world." The plants are always covered with immense blooms, held perfectly erect on long, stiff stems, and seem to be insect-proof. Color a glistening bronzy buff and old gold, blending to a deever shade toward the centre of the flower, reverse of petals a pale flesh color, giving the flower as a whole a warm glow. We have a fine stock of this wonderful Dahlia.

Root $\$ 1.00$

\section{JUNE JUSTICE (Success) (F. Dec.)}

This very unusual colored Dahlia has been the center of attraction in the garden and show-room the strong growing plant is absolutely insect proof It made good at the American Dahlia Society of ficial trial garden at Storrs, Conn., in 1929, which proves that it measures up to the elite of the Dahlia world. It is quite difficult to win a certificate, but "June" was one of the outstanding Dahlias throughout the season and received a cer tificate. Most dark colored Dahlias seem to have a dullness to them, but it is just the opposite in this new creation; the trial garden report reads A mixture of Rhodmine purple and tyrian rose. No color like it in book. Very brilliant in color," Strong stems hold the very large blooms erect. Height 5 feet.

Root $\$ 5.00$. Plant $\$ 2.50$

\section{JEAN TRIMBEE (I. Dec.)}

This beautiful Dahlia is a native of Canada and exhibited at Toronto for the past two years. The flowers are very large, many over 12 inches, and a beautiful rich petunia violet in color. It has a strong, vigorous habit and the large attractive flowers are produced very freely.

Root $\$ 7.50$. Plant $\$ 3.50$

\section{KENTUCKY (Dec.)}

A brilliant light salmon-orange, shading to orange yellow at base of petals and deepening to grenadine pink on outer petals. This great Dahlia has been tested for four years, and its color has never varied a single time. The originator rated the parent of this new Dahlia the best in cultiva. tion, but says we have a better one in the variety Kentucky.

\section{KEMP'S VIOLET WONDER}

The best violet colored Dahlia to date. The predominating color of this great Dahlia is a rich napthaline violet, with an underlying tone of royal purple, with bluish lavender reverse. Flowers are as nearly perfect in form as possible; of true decorative type, and of massive proportions, attaining to a diameter of 10 inches and over, and to a depth of 6 to 7 inches, and are borne on stiff stems 10 to 14 inches above the foliage.

Root $\$ 3.00$

\section{KATHLEEN NORRIS (Dec.)}

The Wonder Dahlia of the Century. A huge flower of clear pink, borne upright on rigid, long stems. Experts say it is the best pink Dahlia in commerce. A winner everywhere in "Court of Honor Class" for largest and best. It has outclassed all other Dahlias of a similar color in all leading shows for past two years. We have a large stock of this wonder Dahlia.

Root $\$ 7.50$. Root $\$ 3.50$

\section{LORD LAMBOURNE (Stredwick)}

Dec.)

The originator claims this to be their largest introduction and describes it as follows: "One of our greatest successes as raisers to date, and we can hardly exaggerate in describing it. The blooms are of tremendous size, and it has a pleasing form, whilst the stems are strong and the blossoms are easily held erect. The color has been described as sunset harmony of pink and gold but the old gold and bronzy tints predominate.

\section{Root $\$ 5.00$. Plant $\$ 2.50$}

\section{LAVINIA BROOMALL (American Cac-} tus)

Very large and unusual in form and color. I know of no other Dahlia that is so different even when grown among the very best new varieties. It attracts immediate attention and will 


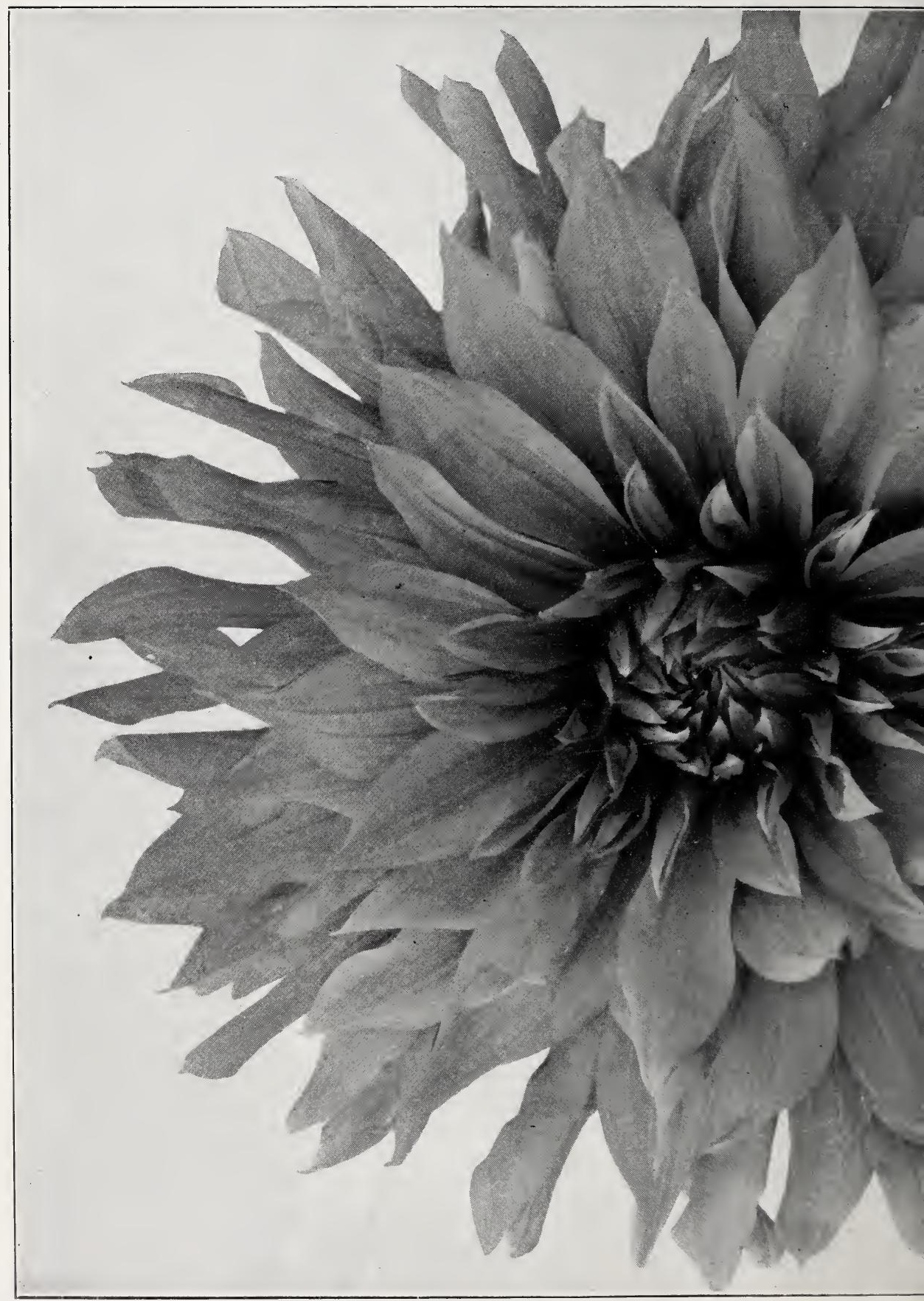


be a valuable addition to any first class collection, as there is nothing like it. A profuse bloomer and the large blooms are held erect on good stems. Color light orange-yellow to capucine yellow, shaded coral-pink. No description can fully describe this new creation. To grow it will be a joy forever. Stock limited. Height, 3 feet.

\section{Root $\$ 7.50$.}

Plant $\$ 3.50$

MARIAN BROOMALL (S. Cac.)

This may be considered somewhat of an old timer by those who grow the more modern Dahlia, but it has and is winning the highest honors competing with the very latest creations. It won the prize for the best Dahlia in the show at San Francisco in 1931 and has won many such prizes since its introduction. We are listing it again, as we consider it an outstanding creation, worthy of a place in any modern collection. It is a twotoned flower of dark lavender pink and white. Large blooms held erect on strong stems above a vigorous growing bush.

Root $\$ 2.00$

\section{MONMOUTH CHAMPION (D.)}

Winner of a special award at Elizabeth, N. J. and as best undisseminated seedling at Red Bank, N. J., where it defeated some of the top notchers. This great Dahlia compares favorably with Fort Monmouth, Violet Wonder, Jane Cowl, Kathleen Norris, and other top notchers of recent introduction. It instantly found favor with all who saw it in our gardens and the show rooms by its great size, and brilliant orange flame color that fairly glistens from its own color. It is the only Dahlia we know in its color. A beautiful Dahlia in the garden and show room and a free producer of large, perfect blooms, on perfect stems through out the season. Plant is a strong, vigorous grower, wide spreading, with long, slender side shoots, each producing a fine exhibition bloom from 10 to 12 inches in diameter that can be cut with stems 2 to 3 feet long.

Root $\$ 5.00$. Plant $\$ 2.50$

\section{MOTHER MACHREE (Dec.)}

Cream or ivory white with a touch of pink at the center. "Something entirely new," a well known authority on Dahlias said. "The color is surely very much out of the ordinary and the great big deep flowers on tall stalks are outstanding in the Dahlia patch. We have watched this variety carefully for four years. There were no faults apparent except that this season it would occasionally throw an open centered flower, due, we think, to the unusually cool weather. We are mentioning this fact, as it is our policy, as we say to our visitors, to tell "the bad along with the good."

Root $\$ 5.00$

\section{MAYFAIR (Dec.)}

Deep old rose with a slight violet suffusion. A big, bold flower, deep and full, and of a very charming color. Long, strong stems that are good early in the season, but will droop slightly as the season advances. Plant is of sturdy growth and is always in bloom. This is a variety that attracts a lot of attention and is very handsome, whether growing or cut.

\section{MAGIC (S. Cac.)}

Wine red. This variety is in a class by itself It is nothing like the maroon hybrids but has a dull silk-like appearance that has not been seen before in Dahlias. The formation is full with well incurved petals and the beauty of the flower is enhanced by a touch of very daik red at the center. Flowers are very large for a good portion of the season and remain closed late into the fall. Stems are good. Plants are of rather low growth and produce well.

Root $\$ 5.00$
MRS. EMILE H. KITSON (I. Dec.) (SUCcess)

One of the most attractive Dahlias in our garden as it is always covered with large blooms held erect on the very best of stems. The attractive color combination appeals to our visitors, the inner petals are of Grenadine pink while the outer petals are pale orange yellow. This origination was awarded a Certificate of Merit at the A. D. S. trial garden at Storrs, Conn., in 1929. It has also won the prize for the best Dahlia in show in strong competition.

Root $\$ 3.00$

MRS. SHIRLEY SHAW (I. Dec.)

Ox blood red shaded maroon, this magnificent flower som times has a tendency to come witl crooked stems, but notwithstanding this fact was more universally admired than any Dahlia in our gardens. The wonderful dark rich color and in. mense size capture everyone. This Dahlia must be seen to be appreciated as it is impossible to describe the beautiful rich blendings from almost black to nearly a scarlet on each petal. It also found its place among the elite of the Dahlia world on the Roll of Honor for 1928. It is a real joy to grow a Dahlia like "Mrs. Shirley Shaw".

Root $\$ 3.00$

MISS HILDA EROOK (Dec.) (Success)

As a seedling this has been one of our most popular Dahlias in our garden on account of its attractive and unusual color combination. Color a rich golden-buff with each and every petal tipped with the purest white. This variety has never failed to come true, every petal tipped white. It is a large bloon variety held erect on good stems.

Root $\$ 2.00$

\section{MILDRED BROOKS HOOVER (Hyb.} Dec.) (Broomall)

(Named by request for sister-in-law of President Hoover.) The originator considers this one of the best Dahlias in his gardens, as the color. Spinel-red, is so different. A most distinct and refined flower, of large size and splendid form. A Dahlia that should be in every first-class collection. Height, 4 feet.

Root $\$ 5.00$

\section{MY MARYLAND}

This extremely hyorid cactus is of a decidedly unique coloring, a blending of unusually delicate pink with the faintest suggestion of lavender, the pointed petals whorl and twist in such a manner as to blend the two colors. There are pinks and there are lavenders, but this flower is in a color class of its own. Excellent stems and leathery foliage. Awarded the Maryland Dahlia Society's gold medal for the best undisseminated seedling exhibited at the exhibition of the New Jersey Dahlia Society in Atlantic City, hence its name. Also awarded the Garden and Home Builder's Achievement medal. First prize at A. D. S. show in New York for best undisseminated hybrid cactus. Certificate of Merit A. D. S. at Storrs.

Root $\$ 3.00$

\section{NEW GLORY (S. Cac.)}

This new creation won several prizes on the Pacific Coast in keen competition in 1930. It is large, standing on a long, stiff stem, vigorous bushes, very free bloomer. A light ox-blood red with tips of petals blazed with white. The petals have a charming quilled effect near points.

Root $\$ 3.00$

\section{NOVA (Dec.)}

Bright old rose of the true old-fashioned shade. There is little variation of color throughout the flower and the tone does not change at different seasons. One could hardly imagine a more fas 
cinating color than the lively richness of this old rose. Large, perfectly formed flowers on the strongest upright stems are produced in profusion from early season until frost kills them down. The formation of this entrancing Dahlia is quite regular with the broad, heavy petals slightly fluted and folding back well against the stem. It is an excellent cut flower, lasting well, and gracing any occasion. We recommend this variety as an out standing introduction.

\section{NEDRA (Dec.)}

Root $\$ 5.00$

I avender pink. Some Dahlias are at their best in mid-season, others improve when the shorte1 days produce slower growth. This Dahlia is at its best in normal weather and can be counted on at show time; in the late fall the centers open. The shade of color is clear and true. The blosson is large and oval shaped with broad, heavy petals continuing well to the small pointed center. Stems are strong anl grow straight out of the bushes. An excellent variety and good for every purpose.

Root $\$ 5.00$

NAVARRE (Dec.)

Flaming orange. In this Dahlia there is color of intense brilliancy. It is as rich and bright as it would seem possible for a color to be. The bloom is only of medium size, but is nowise in significant. Formation and stem are always goorl We have found it very useful for cutting, and it was very popular with those who were looking for varieties for household decoration.

Root $\$ 2.50$

\section{PATRICIA JEAN (Dec.)}

This Dahlia always excites attention in the garden or show room. The flowers can be grown 10 inches and over without disbudding, and the stems are 24-30 inches from the first leaf brack and the flowers are carried erect on the stiff, canelike stems. The color at a distance seems to be perfectly white, but on closer examination shows a straight gray line in the center of the petal. Patricia Jean won the A. D. S. medal at Seattle and the sweepstakes in the one, two and three-year-old seedlings at San Leandro, California, in 1929.

Root $\$ 7.50$

\section{PHYLLIS SHAW (F. Dec.)}

A monstrous flower of apricot orange with reverse of petals jasper red covered with a golden sheen. The blooms are gigantic in size and of great depth. This is a seedling from Elite Glory and has much the same habits in growth, the foliage is very dark green and leathery and is insect proof. Plant is very robust growing, and blooms very freely with good full centers all season. The stems are long and stiff, and hold the blooms well out of the foliage.

Root $\$ 5.00$

\section{POLOMA (Dec.)}

Pale lavender shading deeper toward the edge of the petals. The delicate coloring is both pleasing and unusual. The compact flower is composed of regularly formed petalage which folds back well toward the stem, giving a ball-shaped effect, although it belongs truly to the decorative class. This solid formation makes a special appeal to certain Dahlia fans, and to these we can say that this is a particularly good one of this type, Good stem and prolific bloomer.

Root $\$ 5.00$

ROSE-ELLEN VARBLE (H. C.) (Broom. all)

Beautiful is the one word that describes this Dahlia and we consider it one of our very best introductions. In color it is an entirely new shade of exquisite old rose and coral-pink and was greatly admired by all who saw it. The foliage grows close up to the flower, but by disbudding the habit is such that it can be grown with long. straight stems. Height, 5 feet. Stock limited.

Root $\$ 5.00$

FOSINA MEHAFFEY (Dec.)

II e all admire the large ones and in this new variety we find our want fulfilled to the uttermost. We like good vigorous growers that are insect proof. We have it here. I do not know how large they can be grown if disbudded, but we cut many 9.10 inch off plants not disbudded or pruned, so judge for yourself. Color tyrian-pink. Fine strong stems holding the big blooms erect.

Root $\$ 5.00$

\section{RAJAH (Hyb. Cac.)}

Golden orange with a gold reverse. Decidedly in the cactus class, the nicely incurved petals being rolled their entire length. In addition, the centers and stems are always good, and there is no waste through imperfect flowers. Plant is of medium height and is very floriferous. If carefully disbudded the blooms can be grown to exhibition size. Excellent for cutting

\section{RAPIDAN (Dec.)}

Golden bronze. A huge symmetrical flower borne upright on an extra long, thick. stem. A dozen perfect blooms can be cut from the plant at one time and little disbudding is required. These features combined with the lively coloring which is exactly what the florists want, has already made Rapidan invaluable as a commercial variety. A leading San Francisco florist took every bloon we could supply and said there was no worry about them keeping fresh. It might be called a cut-and-come-again variety, as crop after crop of choice blooms succeeded each other through the whole season. Not spectacular but absolutely re liable and ornamental. 1930 Roll of Honor Dahlia.

\section{RED LION (Dec.)}

Root $\$ 10.00$. Plant $\$ 5.00$

Bright red. Another large Dahlia that serves the florists' purpose well. A vivid red is always desirable when it has all the good qualities which this Dahlia possesses. Quantities of first-class blooms loaded the bushes until the very end, which never fade or burn. Stems hold the flowers just right, whether desired for garden display or for the house. The bloom is oval shaped witl broad, heavy petals continuing well to the small pointed center.

Root $\$ 5.00$. Plant $\$ 2.50$

\section{ROYAL FLUSH (Dec.)}

Brightest scarlet. A sensational variety both as to color and size. One bloom we measured was $111 / 2$ inches and there were larger ones. Con sidering that our Dahlias receive only ordinary field culture, such blooms demonstrate the pos. sibilities of this flower. Furthermore, the brilliant coloring seems also to accentuate the size. The formation is full and deep and the stem strong and sufficiently long. Performance was fine all season. On the American Home Roll of Honor for 1930. We do not hesitate to boost Royal Flush.

\section{SULTANA (Dec.)}

Root $\$ 10.00$. Plant $\$ 5.00$

Bright scarlet shading to a gold center, the brightest, most pleasing color imaginable, of velvet. like texture, reverse of petals also gold. Here is another Dahlia of enormous size, which continues until quite late, but it was at the height of the season that this variety made its special appeal. It is one of those that calls to you from across the field, and there are still many people whose favorite color in Dahlias is red. This is one that is hard to beat in its class and has every good quality.

Root $\$ 5.00$ 


\section{SISKIYOU (S. Cac.)}

Siskiyou grows to enormous size and has created a sensation wherever it is grown. Plants are very strong and vigorous. Blooms are held erect on strong stenis. Color is pink, tinged mauve.

Root $\$ 1.50$

\section{THE WORLD (Dec.)}

This wonderful new Dahlia was selected at the A. D. S. Show in New York by Mr. J. D. Sullivan of the New lork World. The coloring is an unusually rich, deep rosy magenta overlaid garnet with silver shadings on elges of petals. I rich and beautiful combination of colors. Perfect, full centers. Stems are strong and erect. Foliage leathery and repellent to insect injury. This greatly admired Dahlia is sure to pleas: you. Stock of tubers limiterl.

Root $\$ 3.00$

\section{THOS. HAY}

A giant in very truth, of clear lilac color throughout, flowers deep, full and massive, with loroad florets bluntly pointed. The stems carry the huge flowers with ease, and the plants flower with surprising freedom. This variety is almost identical in every way (except for its lilac color) to the now famous "Berengaria". One of the best Dahlias in our garden.

Root $\$ 1.00$

\section{THOMAS A. EDISON}

This gorgeous new royal purple exhibition lecorative, selected and named by permission of the famous electrical wizard, met with his complete approval when viewed at his West Orange estate. The staghorn petal formation, the dark green in. sect-resisting foliage, the cane stiff stems, and its thrifty growing habit leave nothing to he desired. Root $\$ 5.00$. Plant $\$ 2.50$

VOGUE (Dec.)

Bright salmon, or peach, as some cut flower customers insisted on calling it. This fine me- diun-sized Dahlia is primarily a cut flower variety. It keeps a week or longer when cut and is of a color that seems especially adapted to that purpose. Best of stems, freedom in blooming, but not very large. A plant in the garden itself looks like a bouquet.

\section{WALDHEIM SUNSHINE}

Root $\$ 2.50$

This giant yet graceful Dahlia is one of the best. A true deep yellow that will show up yellow tnder artificial light. The reflex is darker, and there is a rich golden suffusion around the beautiful full, high center. The bush growth is good, stems are strong and erect. It is a sturdy grower and free bloomer. The centers were perfectly full when killed by frost.

WILLIAM H. HOGAN (Dec.)

Root $\$ 2.00$

IIinner first prize New York 1927. This is one of those Dahlias that must be seen to be appreciated. Color, garnet-red with white tips running down the center of the petals. Perfect stems. Mr. Derrill W. Hart says: "William H. Hogan, this heavily textured flower, carried out the prediction that we made for it last year, namely: that it was the best of the fancy varieties shown in 1927." It is without doubt the best fancy Dahlia on the market to date. The habits of the plant are perfect, the very large blooms are carried on very long, stiff stems. It's a winuer.

Root $\$ 2.00$

\section{"YORK \& LANCASTER" (Dec.)}

An exceptionally fine exhibition or cut flower. The blooms are very large, a fine exhibition or cut flower. The blooms are of fine form, held erect on three foot, stiff stems. It has splendid keeping qualities when cut. There is nothing to compare with the beauty, color, a bright crimson, each petal tipped pure white. 1 good tuber producer.

Root $\$ 3.00$

\section{HERE THEY ARE}

\section{Just what you have been looking for!}

A soft-pliable-ALL-LEATHER-dirt proof glove for both MEN and WOMEN-specially adapted for general home use such as-Garden and Lawn, Garage, Furnace, Housework and Driving.

\section{SOFT AS KID}

ALL LEATHER

Pliable, unhampered use of fingers.

\section{THE IDEAL}

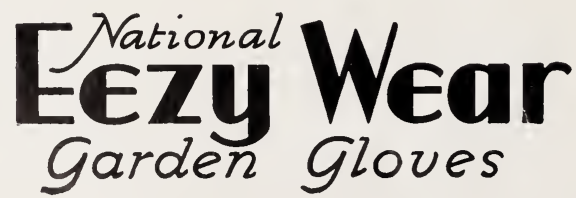

\section{Order By Size}

\section{Women's \\ Men's \\ One Pair $75 \mathrm{c}$}

Small or Med. Large or Med.

or Two Pairs $\$ 1.40$ 


\section{MARGARET E. BROOMALL'S ANNOUNCEMENT}

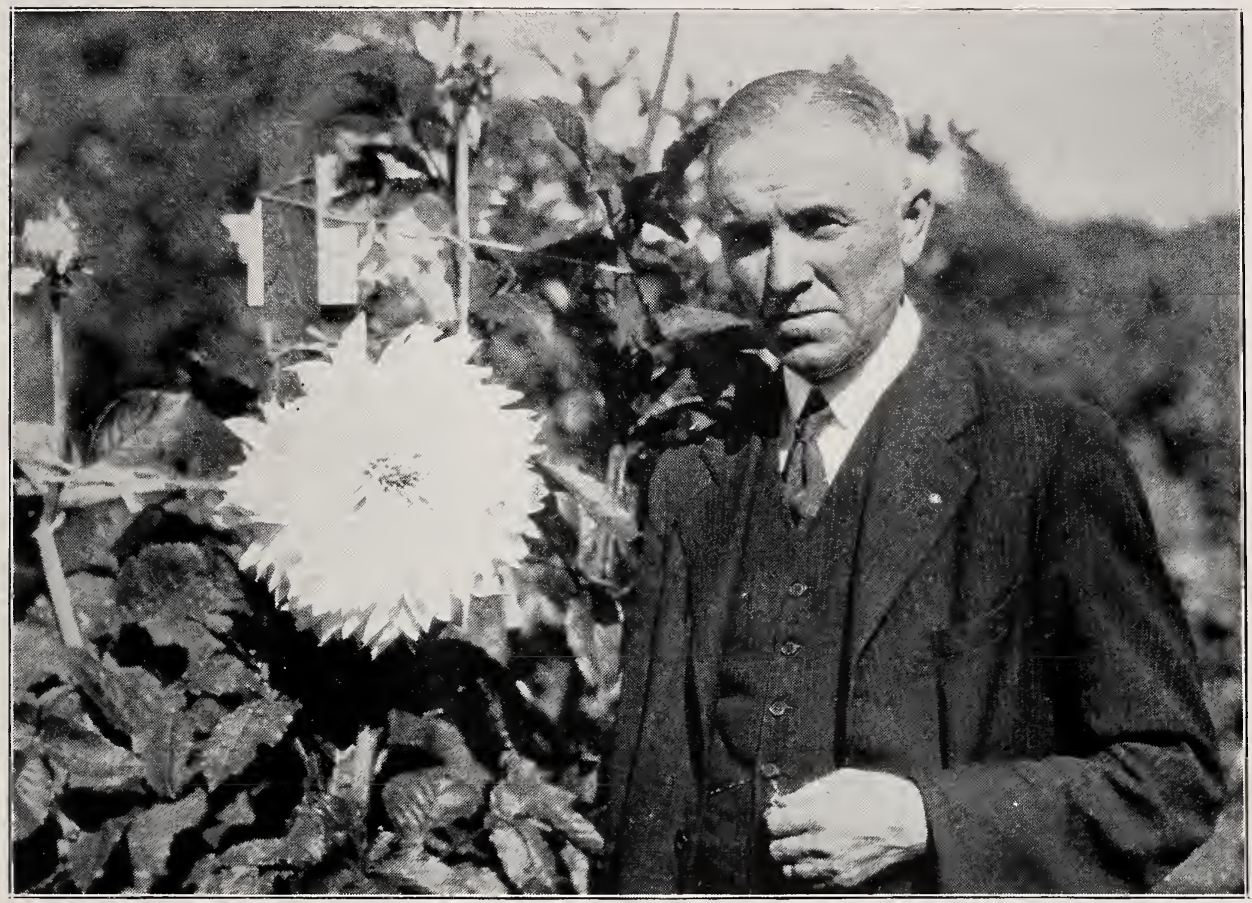

MARGARET E. BROOMALL GROWING IN OUR TRIAL GARDENS

\section{(Patent Pending)}

In reply to many inquiries regarding the release of this new variety.

This remarkable Dahlia was not exhibited in any show in 1931, except in our regular display.

It was entered at the official Trial Garden at Storrs, Conn., where it received the highest score ever given a Dahlia, 93.5.

We plan to release "Margaret E. Broomall" for the 1933 season, when we shall have stock to release at a price you can all afford, the first season out.

It is probable that we shall publish late this season a short story about this Dahlia. If you are interested to receive a copy, please advise.

IN CASE OF A PATENT BEING GRANTED "MARGARET E. BROOMALL" BEFORE PLANTING TIME THIS SEASON, WE MAY RELEASE A FEW PLANTS OF THIS VARIETY THIS YEAR.

If you desire to receive advance releases, please advise. This will place you under no obligation. But we will advise of release and price. 


\title{
THE FUTURE OF THE DAHLIA
}

\author{
By J. J. Broomall
}

I have been asked if we are to have better Dahlias in the future; to this question I will reply that beyond a doubt much better Dahlias will be produced in the future than those we have at present.

Notwithstanding the progress that has been made in the past third of a century in the culture and development of new varieties we are yet a long way from perfection.

My idea of the PERFECT DAHLIA would be a flower of perfect form at least moderately large, set on a strong, straight stem so that it will look the passerby right in the face. Tastes differ as to color, but my first choice would be a pure pink, either in rose pink or salmon pink shades, but entirely free from any mauve, lavender, or magenta shades or tints; my second choice in color would be in tawny orange, or mars orange tints ; my third choice as to color, coral, or old rose.

Most important of all it must have good keeping qualities, for THE DAHLIA OF THE FUTURE MUST BE A GOOD CUT-FLOWER DAHLIA.

When we get a Dahlia with all the good points I have mentioned combined with a color so attractive that it will compel immediate attention, then in my opinion we will have the PERFECT DAHLIA.

Some may think that it will be impossible to obtain such a Dahlia as I have endeavored to describe; to my mind nothing is impossible in this day and age concerning the improvement of plants by hybridizing, intensive cultivating and selection.

We cannot expect to see such a perfect flower in one year; that is very improbable, but with intelligent endeavor we may reasonably look forward to some improvement each succeeding year.

To a great extent the growing of seedling Dahlias in the past has been carried on in a more or less haphazard manner without regard to parentage or scientific breeding, with the result that a great number of seedlings have been put on the market that did not have sufficient merit to justify their introduction.

This condition of affairs should be rigidly guarded against, for nothing will do more to cause the public to lose interest in the Dahlia than the indiscriminate introduction of large numbers of mediocre varieties.

I do not believe that the public in general, and amateur growers in particular, will lose interest in the Dahlia if new varieties of merit are introduced. People like new things and beautiful flowers just as much now as they ever did, and it is up to the Professional Growers to supply new varieties of sufficient merit to awaken a desire for them among the flower-loving public. 


\section{THE PRICE OF A GOOD DAHLIA}

Many amateurs are inclined to think that the prices asked for new varieties are exorbitant; few of them have any idea of what it costs to produce good variety. If I were to tell them that a variety that is listed at $\$ 25$ or $\$ 50$ per root cost the originator $\$ 500$ or $\$ 1000$ to produce they would think I was exaggerating; having had some experience in producing some Dahlias that are considered worth growing, I am going to tell something of my experience in growing them, and then you are welcome to form your own conclusions as to what they may have cost.

For the last ten years I do not think that on the average I have listed in my (or other) Catalogues more than three out of each thousand seedlings I have raised and not more than one out of each three has stood the test of time in the flower buyers markets.

The year I grew Eagle Rock Beauty (1925) I raised more than ten thousand seedlings and while I obtained a few others of merit that year I regarded the one just mentioned as the best out of the ten thousand.

On account of very limited stock I put Eagle Rock Beauty on the market in 1926 at $\$ 50$ per plant; not that I expected to sell many at that price but I wanted to let people know that I had it, and I did not want to sell short on it, for I have learned from experience that it is ruinous to sell short on a new variety when it is first introduced, for the originator will never receive what it has cost him to produce it.

Now, then, what did it cost to produce it? Those ten thousand seed lings of which more than 95 percent were discarded as soon as they bloomed had to have the best possible culture in order to determine their merits, the growing and care of them coupled with the incidental expenses represented nearly a whole season's work for one man. Now if no one is willing to pay a good price for a flower that has taken so much labor to produce, how is the grower going to come out even on the proposition, to say nothing of making a living?

I know that there are growers that introduce many more than three in each thousand BUT how many prize-winners have they put on the market, and what have they done to improve the excellence and popularity of the DAHLIA? If anyone has found a way to get a worthwhile Dahlia without a lot of labor I must acknowledge that they have beaten me, for so far I have found no easy road to success.

To obtain anything of great merit generally requires intelligent effort and a lot of it; and if we would have the admiration and support of the people we must do our best to deserve it. 


\section{SATAN (SEMI-CACTUS) (BALLAY)}

Flaming red with a slight touch of gold at the center. The exquisite coloring is at once fascinating, but what formation and stems. The blooms regularly measure 10 to 12 inches in diameter and 6 inches in depth, and the large horn-like petals, so perfectly rolled and incurved give rare form and character to a flower of unusual brilliancy. The rugged, almost leafless stems give the impression of being nearly as thick at the top as at the base. Large, fine blooms, which last a long time when cut as well as on the bush, continue to the very end of the season. Derrill W. Hart describes this variety as follows in the American Home Honor Roll for 1931. "This flaming scarlet with orange-salmon at the base of each petal was not shown in the East, but we saw it growing at Lawrence, Mass. The blooms are beautifully formed and the bush is a fine grower. Surely this variety will be a temptation to any Dahlia fan and better still he will not give himself cause to regret in yielding to this color sensation, one of the most brilliant we have seen in a Dahlia. Only a few Dahlias would feel comfortable near this one."

Satan was the Dahlia sensation on the Pacific coast this year where it has already made for itself a place on the American Home Roll of Honor. Its performance in the East has been equally as good as in the land of its nativity.

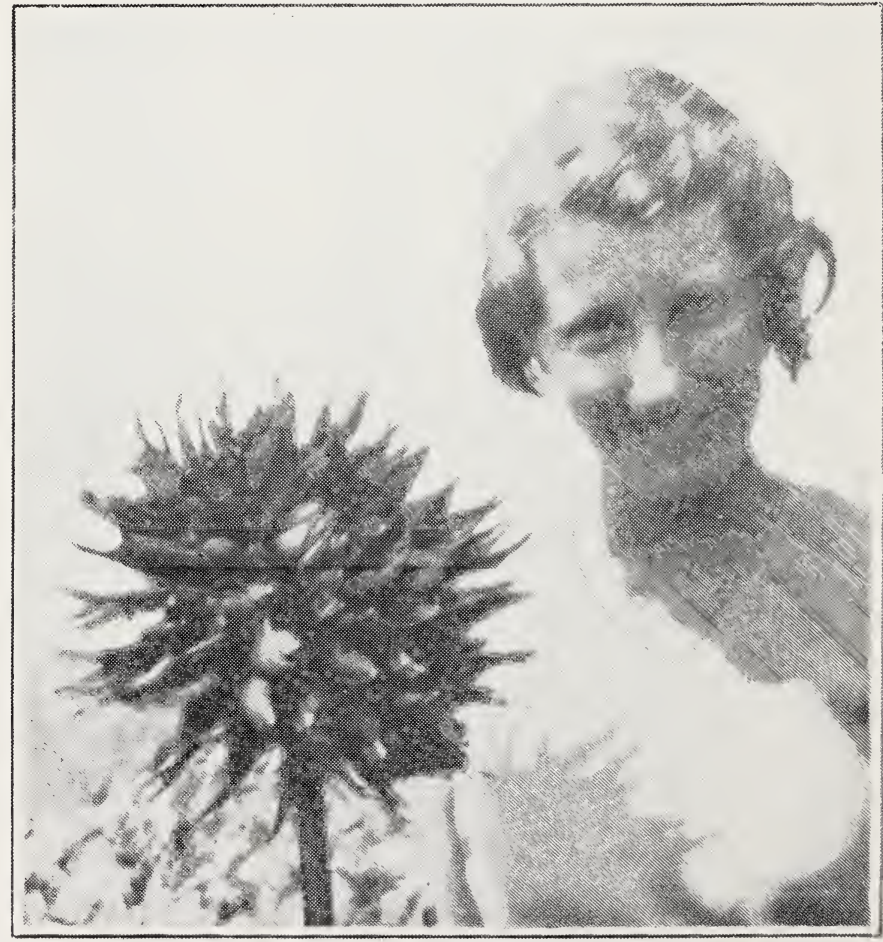

SATAN

The sensational Dahlia of the Pacific Coast in 1931. (Patent Pending)

(See Page 8) 


\section{ORDER SHEET \\ Issued by \\ SUCCESS DAHLIA GARDENS}

171 FERRY STREET, LAWRENCE, MASS.

Date

Amount Enclosed.

Your Name.

(Write it plainly. Ladies will please use the prefix Miss or Mrs.)

City

State.

Street. . . . .

County.

Shall we substitute for any that are sold out?

About what date do you want them shipped?.

\begin{tabular}{l|l|l|l}
\hline HOW & HOW \\
MANY MANY \\
ROOTS
\end{tabular}




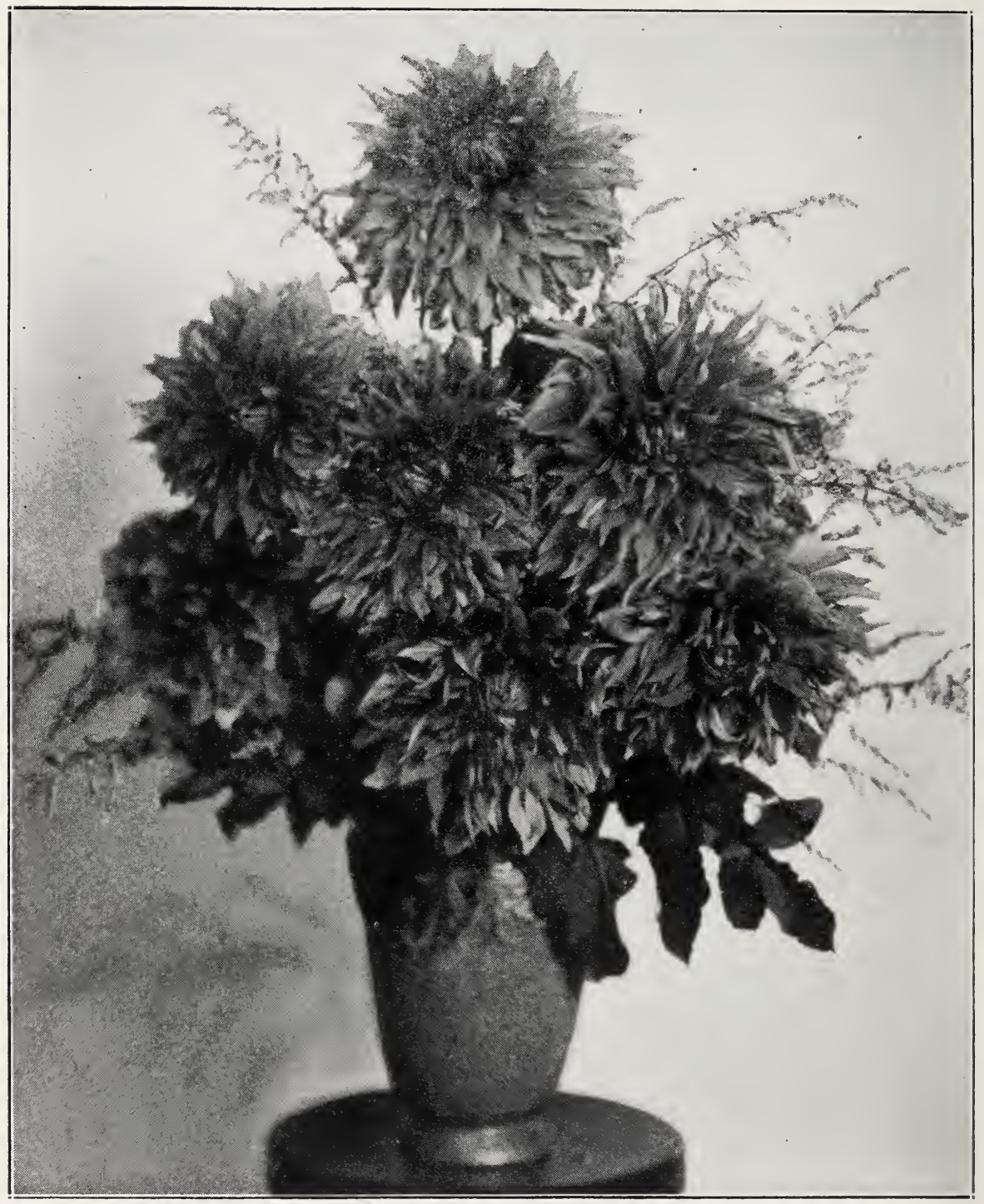

INDIANA MOON

A very large Dahlia that is worthy of a place in any high class collection. 


\section{JOIN THE AMERICAN DAHLIA SOCIETY, INC.}

Wm. J. Rathgeber, Sec'y,

198 Norton Street, New Haven, Conn.

I extend to you a most cordial invitation to join this live organization that has done so much in making the Dahlia the most talked of flower in the world today. There are four fine Bulletins issued each year devoted almost exclusively to the Dahlia and they are brimful of interesting articles written by the amateur and commercial grower. They tell you all about the new Dahlias, the trial garden report, how to grow Dahlias, reports of the Dahlia shows, etc.

I am sure that the secretary will be pleased to send you a sample copy of the Bulletin on request. Don't wait, send in your $\$ 2.00$ today which pays for your dues and subscription for the Bulletin for one year.

CHARLES G. REED, Vice-President.

\section{AMERICAN DAHLIA SOCIETY OFFICIAL TRIAL GARDEN \\ Storrs, Conn.}

Hundreds of our customers are growing seedlings and of course many think they have better seedlings or as good as some of the high priced Dahlias and perhaps they have. BUT to be sure they should send them to this garden and this is one way to find out. It will cost you just $\$ 3.00$ for each variety that you send, but you may send three roots or plants of each variety with no extra charge; this insures the sender that at least one plant should be at its best at judging time. The clumps made from your varieties will be returned to you in tho fall after digging if you wish, but you must pay the return express charges which amounts to very little. Why not send at least one variety this year and more if possible and what a fine investment if you produce a winner. Remember Jane Cowl, Elite Glory, Jersey Beauty, Alice Whittier and hundreds of other great Dahlias receiver' their start at the trial garden at Storrs. Just drop a line to Prof. Roland H. Patch, Storrs, Conn.. and he will gladly send you full instructions when to ship, etc. We expect to have a glorious garden to greet the visitors next season. Help us make it so. Please.

CHARLES G. RFED, Chairman, Trial Garden Committee.

\section{NATIONAL ASSOCIATION OF COMMERCIAL DAHLIA GROWERS, INC.}

Every reputable commercial dealer or grower should join this live association. Purchasers of Dahlia stock are assured of a "Square Deal" if they purchase stock from a member. For full particulars drop a line to Mr. Thomas Leavitt, Sec'y, Assinippi, Mass.

CHARLES G. REED,

Organizer and Past President. 


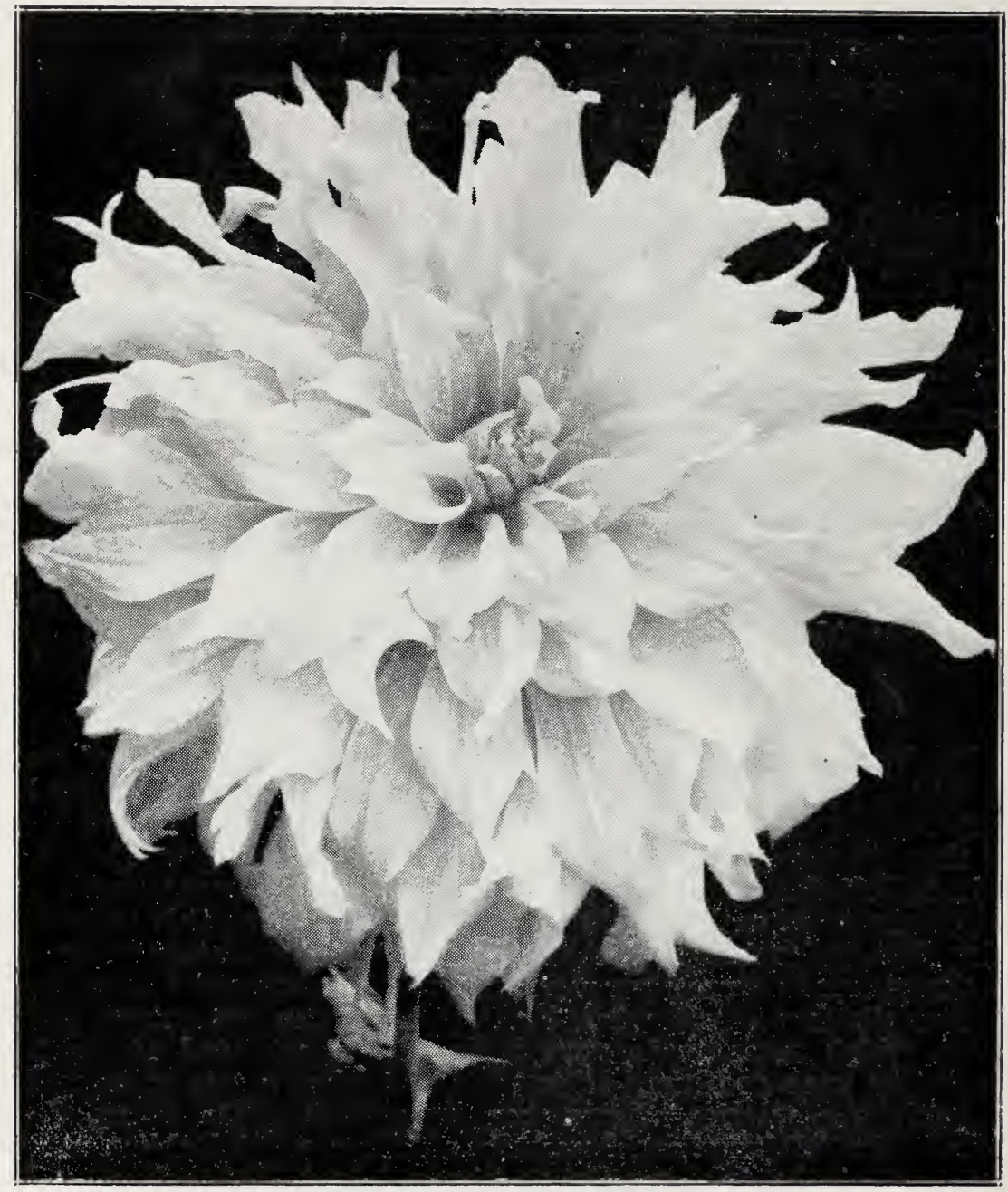

\section{EAGLE ROCK FANTASY}

A most popular Dahlia whereever shown in 1931. Winning many prizes for the best in the show. It's great beauty and size makes it a strong contender for the major prizes in any competition.

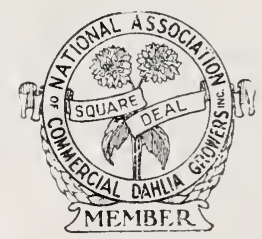

Remember we are members of the National . Issociation of Commercial Dahlia Growers, Inc. which guarantees a "SQLARF. DEAL" to the customers of its members.

Member American Dahlia Socicty, Inc; Dahlia Society of New Jersey; Dahlia Society of New England; Dahlia Society of San Francisco: Dahlia Society of California; Massachusetts Horticultural Society: Dahlia Society Southern ('alifornia.

Reference: Merchants Trust Co, Lawrence, Mass, or any reliable Dahlia grower in the world. 